\title{
STRATEGI PEMANFAATAN MEDIA SOSIAL SEBAGAI MEDIA PENDIDIKAN ISLAM INFORMAL PADA REMAJA: SOLUSI DI MASA PANDEMI COVID-19
}

\section{STRATEGY FOR THE UTILIZATION OF SOCIAL MEDIA AS AN INFORMAL EDUCATION MEDIA FOR ADOLESCENTS: SOLUTIONS IN THE PANDEMIC OF COVID-19}

\author{
Anhar Anshori ${ }^{1}$, Shaleh ${ }^{2}$ \\ ${ }^{1}$ Fakultas Agama Islam, Universitas Ahmad Dahlan \\ ${ }^{2}$ Fakultas Ilmu Tarbiyah dan Keguruan, UIN Sunan Kalijaga \\ email: anharanshori52@gmail.com,shalehmaruf.413@gmail.com
}

Naskah Diterima: 12 Agustus 2020; Direvisi: 17 Agustus 2020; Disetujui: 28 Agustus 2020

\begin{abstract}
This article discusses the use of social communication media in the field of Islamic education (informal) for adolescents as a solution during the COVID-19 pandemic. As it is known, social media is a modern means of communication that millennials cultivate, love, and update at any time. This study intends to examine appropriate strategies in the use of these media as a means of instilling friendly and peaceful Islamic values. For this purpose, researchers conduct field studies (field research). The research data were collected by combining in-depth interview techniques and observation with literature studies. In the literature study, the researcher adopted six research steps, namely: literature collection, use of literature classification checklist, content analysis, preliminary formulation of study results, literature review, and formulation of research conclusions. The results of this study indicate several conclusions that the strategies that can be carried out are: (1) choosing social media platforms based on priority, (2) paying attention to the needs of adolescents, (3) choosing and packaging interesting and attractive content, (4) Using a persuasive-humanist approach, and (5) featuring a friendly Islamic sharing platform.
\end{abstract}

Keywords: Covid-19 Pandemic; Islamic education; Social media

\begin{abstract}
Abstrak
Artikel ini membahas tentang pemanfaatan media komunikasi sosial dalam bidang pendidikan Islam (informal) pada remaja sebagai solusi di masa pandemi COVID-19. Sebagaimana diketahui bahwa medsos merupakan sarana komunikasi kekinian yang setiap saat digeluti, digandrungi, dan di-update oleh generasi millennial. Penelitian ini bermaksud untuk mengkaji strategi-strategi yang tepat dalam pemanfaatan media tersebut sebagai sarana untuk menanamkan nilai-nilai Islam yang ramah dan damai. Untuk kepentingan ini, peneliti melakukan studi lapangan (field research). Data penelitian dikumpulkan dengan mengombinasikan teknik wawancara mendalam (in-depth interview) dan observasi dengan studi literatur. Pada studi literatur, peneliti mengadaptasi enam langkah penelitian, yaitu: pengumpulan literatur, pemanfaatan checklist pengklasifikasian literatur, analisis konten, perumusan awal hasil kajian, reviu ulang kepustakaan, dan perumusan simpulan penelitian. Hasil penelitian ini menunjukkan beberapa simpulan bahwa strategi yang dapat dilakukan, yaitu (1) memilih platform media sosial berdasarkan prioritas, (2) memperhatikan kebutuhan remaja, (3) memilih dan mengemas konten yang menarik dan atraktif, (4) Menggunakan pendekatan persuasif-humanis, dan (5) menampilkan platform syiar Islam yang ramah.
\end{abstract}

Kata kunci: Media sosial; Pendidikan Islam; Pandemi Covid-19 


\section{PENDAHULUAN}

Teknologi telekomunikasi mengalami perkembangan yang sangat pesat seiring dengan hadirnya gawai pribadi (gudget) yang mampu menghadirkan berbagai fitur komunikasi sosial yang menarik. Teknologi ini telah menawarkan kemudahan bagi umat manusia untuk menerima dan mengirimkan pesan, baik kepada individu maupun kelompok melalui vitur-vitur pesan yang atraktif. Saluran komunikasi tersebut kemudian membentuk suatu entitas komunal yang mewadahi setiap anggotanya dalam suatu jejaring media yang popular disebut sebagai media sosial (medsos). Media komunikasi ini memiliki jangkauan yang dapat menembus sekat-sekat fisik dan batas-batas wilayah budaya (Triastuti, 2019), sehingga menjadi sarana yang sangat efektif untuk membangun sebuah wacana. Karena memang praktek dan medium komunikasi media sosial dapat berperan sebagai sarana yang mampu mempengaruhi presepsi penerimanya dalam lingkup suatu budaya atau dalam suatu tataran sosial tertentu.

Media sosial merupakan inovasi yang terus melaju dengan pesat dan menjadi sebuah industri yang sangat dinamis. Hal ini didukung dengan kondisi bahwa Indonesia adalah salah satu negara pengguna internet terbesar di dunia. Data yang dilaporkan oleh Asosiasi Penyelenggara Jasa Internet Indonesia (APJII, 2019) menunjukkan bahwa angka pengguna internet di Indonesia mencapai 171,17 juta pengguna dari populasi 264,16 juta jiwa. Dengan angka tersebut, menjadi sangat menarik untuk memberdayakan sektor industri digital di di dalam berbagai bidang kehidupan. Inilah yang menyebabkan pemanfaatan internet sebagai media komunikasi sosial dengan berbagai motif, baik sosial, ekonomi, budaya, politik, termasuk pendidikan.

Lanscape media sosial dapat dilihat dari laporan Hootsuite pada tahun 2019. Total populasi penduduk dunia sebesar 7,676 milyar, dengan pengguna mobile unik sebanyak 5,112 milyar, pengguna internet sebanyak 4,388 milyar, pengguna media sosial aktif sebanyak 3,484 milyar, dan pengguna media sosial mobile sebanyak 3,256 milyar. Sedangkan di Indonesia, total populasi sebanyak 268,2 juta jiwa (mengalami kenaikan sebesar $1 \%$ atau sekitar 3 juta jiwa dari tahun 2018), pengguna mobile unik sebanyak 355,5 juta jiwa (mengalami penurunan sebesar 19\% atau sekitar 83 juta jiwa dari tahun 2018), pengguna internet sebanyak 150 juta jiwa (mengalami kenaikan sebesar $13 \%$ atau sekitar 17 juta jiwa dari tahun 2018), pengguna medsos aktif sebanyak 150 juta jiwa (mengalami kenaikan sebesar $15 \%$ atau sekitar 20 juta jiwa dari tahun 2018), pengguna media sosial mobile sebanyak 130 juta (mengalami kenaikan sebesar 8,3\% atau sekitar 10 juta jiwa dari tahun 2018) (Riyanto, 2019). Angka-angka ini menjadikan Indonesia menempati peringkat keempat terbesar sebagai pengguna media sosial di dunia setelah India, Amerika Serikat, dan Brazil (Tribunnews, 2019). Angka tersebut akan terus naik seiring dengan laju pertumbuhan regulasi dan infrasturktur yang mengarah pada transformasi digital menapaki era industri 4.0. Hal ini menarik untuk dikaji secara mendalam tentang bagaimana memanfaatkan ruang pada media komunikasi sosial guna mendistribusikan nilai-nilai pendidikan Islam dalam rangka mendorong laju transformasi sosial menuju masyarakat adil dan sejahtera, lahir dan bathin, di dunia-akherat. Terlebih lagi, di masa pandemi COVID-19 yang melanda dunia saat ini, model pembelajaran berbasis teknologi digital menjadi solusi tepat guna mendukung kebijakan Pembatasan Sosial Berskala Besar (PSBB).

Persoalan yang muncul kemudian, bagaimana memanfaatkan media komunikasi sosial ini yang dapat merangkul generasi muda untuk lebih mengenal wajah Islam yang rahmatan lil 'alamin. Hal ini diperlukan untuk menghalau pengaruh konten-konten ke-Islaman yang berhaluan paham keagamaan nonmainstream, bahkan radikal. Konten tersebut seringkali mengembangkan provokasiprovokasi kebencian antar sesama anak bangsa dan berdampak buruk terhadap pesan utama Islam sebagai rahmat bagi alam semesta. Dalam konteks inilah dibutuhkan kajian yang mendalam untuk merancang strategi-strategi dalam memanfaatkan media komunikasi sosial sebagai sarana dalam membumikan nilai-nilai Islam yang ramah dan cinta damai.Lebih-lebih lagi saat ini sedang mewabahnya covid19 dimana masyarakat terutama remaja lebih 
banyak menggunakan

kesempatan menggunakan media social.

\section{KAJIAN TEORI}

Pendidikan memiliki peranan besar dalam proses transformasi sosial (Wahid, et al, 2018: 3). Peran ini menuntut sebuah strategi dan inovasi dalam merespons setiap jengkal peluang yang dapat dimanfaatkan untuk meningkatkan kinerjanya. Salah satu strategi yang perlu dikembangkan adalah sarana pembelajaran kekinian yang efektif agar dapat menggulirkan proses transformasi tersebut dengan baik. Era digital telah menawarkan media sosial yang akrab dengan keseharian generasi muda, bahkan saat ini juga digandrungi oleh orang dewasa. Media ini memiliki jangkauan yang mendunia, sehingga menjadi sarana yang baik dalam mentransmisikan nilai-nilai pendidikan kepada para generasi muda di seluruh pelosok negeri, bahkan menjangkau masyarakat di sudut-sudut dunia. Media sosial terbangun atas kecakapan teknologi informasi (online) yang kemudian digunakan oleh masyarakat untuk membangun berbagi opini, pencitraan, pemahaman, pengalaman, dan perspektif tentang berbagai produk, baik ekonomi, budaya, dan juga agama.

Pada dekade terakhir ini, penggunaan teknologi komunikasi terus meningkat seiring dengan kebutuhan akan media komunikasi yang cepat, mudah, murah, dan memiliki jangkauan luas. Teknologi ini telah mempertemukan berbagai latar kebudayaan dari seluruh belahan dunia menyatu dan berkomunikasi di dalam alam maya. Di sinilah kebudayaan dan sistem sosial dalam masyarakat milleneal terbentuk dalam suatu relasi dua arah atau lebih melalui keterhubungan pesan dengan penerimanya. Proses komunikasi ini kemudian menggulirkan roda transformasi sosial (Taufiq \& Utama, 2018) melalui opini, presepsi, pemahaman, dan kesadaran yang dibangun melalui media sosial.

Teknologi media sosial telah menggulirkan perubahan kehidupan masyarakat. Masyarakat pada saat ini telah memiliki ketergantungan kepada teknologi, sehingga mengakibatkan munculnya tatanan masyarakat dengan wajah baru berdasarkan pada kemampuannya untuk menggunakan teknologi (Griffin, 2003). Teknologi media komunikasi merupakan sarana untuk membangun eksistensi manusia melalui ide, gagasan, dan pemikiran, telah berpengaruh besar dalam proses perubahan budaya (Morissan dkk, 2002: 31).

Dick Hebdige (2001:5) dalam karyanya yang berjudul "Subculture: The Meaning of Style" menjelaskan bahwa dalam konteks kebudayaan, peristiwa komunikasi terbuka dapat menciptakan efek transformatif yang menjadi pendorong bergulirnya transformasi sosial. Transformasi sosial merupakan produk akhir dari proses komunikasi yang dilakukan oleh berbagai pihak dalam mengembangkan ide, gagasan, opini, persepsi, pemahaman, dan kesadaran. Hal ini bertautan dengan proses pendidikan yang hendak membangun pemahaman dan kesadaran akan nilai-nilai luhur, termasuk nilai-nilai keagamaan. Nilainilai tersebut bergerak dalam tataran peristiwa komunikasi yang mengarah pada sebuah perubahan dan juga kritik terhadap kondisi suatu komunitas manusia (Arkoun 1994: 45). Di sinilah letak keterhubungan antara pendidikan agama dengan teknologi komunikasi digital masa kini. Pendidikan agama seharusnya hadir untuk mengisi ruang teknologi komunikasi sosial, sehingga dapat menjangkau subjek pendidikan secara lebih luas. Para edukator pendidikan Islam harus mampu berperan dalam memberikan kontribusi positif atas boomingnya medsos di berbagai penjuru dunia. Media tersebut dapat dijadikan sarana internalisasi nilai-nilai luhur agama dalam kehidupan seharihari melalui konten-konten ajaran agama sebagai penebar perdamaian dan kasih sayang bagi sekalian alam (rahmatan lil alamin). Jika media komunikasi sosial ini berisi banyak konten tentang nilai-nilai ajaran Islam yang ramah, maka akan berperan untuk menkonter paham-paham keagamaan yang bersifat ekstrimis-radikal.

Upaya untuk memadukan pendidikan agama dengan media komunikasi sosial merupakan inovasi bidang pendidikan yang sangat diperlukan dalam tatanan era revolusi digital saat ini. Pendidikan Islam yang saat ini beroperasi dalam sebuah prosedur formal harus mulai bergerak ke ranah-ranah prosedur informal berbasis teknologi digital. 
Teknologi media komunikasi sosial dalam bentuk media sosial seperti Facebook, Youtube, Instagram, Twiter, dan Linkedin menjadi sarana penanaman pemahaman yang menarik, efektif, dan kekinian. Media informasi ini dapat melampaui sekat fisik tradisional lembaga pengajaran seperti sekolah, pesantren, masjid, dan majelis taklim. Terlebih lagi di masa pandemi covid-19, pembelajaran berbasis teknologi digital sangat diperlukan. WHO telah menyatakan bahwa "dunia masuk ke dalam masa darurat global" seiring dengan merebaknya covid-19 sejak bulan Januari 2020. Langkah-langkah yang telah dilakukan oleh pemerintah dan masyarakat untuk mengantisipasi virus ini, salah satunya adalah dengan gerakan physical distancing (Buana, 2020). Hal ini tentu menutut sebuah tatanan baru di berbagai bidang, termasuk bidang pendidikan untuk dapat melakukan inovasiinovasi melalui kajian-kajian dan penelitian dalam menghadapi tantangan di masa pandemi ini.

Penelitian tentang pemanfaatan media komunikasi sosial sebagai media pembelajaran telah dilakukan oleh para ilmuan bidang Pendidikan. Beberapa di antaranya: Sindang (2013) tentang Manfaat Media Sosial dalam Ranah Pendidikan dan Pelatihan, Akbar (2018) tentang Pengembangan Video Pembelajaran Matematika Berbantuan Media Sosial Instagram sebagai Alternatif Pembelajaran, Abidin \& Fahmi (2019) tentang Media Sosial dalam Mempengaruhi perilaku Keberagamaan Siswa dan solusinya melalui Pendidikan Agama Islam, dan Ainiyah, (2018) tentang Remaja Millenial dan Media Sosial: Media Sosial Sebagai Media Informasi Pendidikan Bagi Remaja Millenial. Penelitianpenelitian ini telah memaparkan peranan dan pengaruh media sosial dalam proses pendidikan, dimana diakui bahwa media sosial diakui memiliki pengaruh besar pada generasi millennial. Yang belum dibahas oleh para peneliti adalah bagaimana strategi untuk memanfaatkan media sosial tersebut sebagai sarana pendidikan Islam.

\section{METODOLOGI}

Penelitian ini merupakan penelitian
lapangan dengan pendekatan dekriptif
kualitatif. Peneliti melakukan pengumpulan data dengan mengombinasikan teknik wawancara mendalam, observasi, serta studi literatur. Informan (narasumber) pada penelitian ini dipilih dengan teknik pusposif, terdiri dari remaja pada usia 14-18 tahun, orang tua/wali, dan guru. Adapun analisis data penelitian ini menggunagakan teknik Miles, Huberman, \& Saldana (2014), yang terdiri dari kondensasi data, penyajian data, dan penarikan kesimpulan/verifikasi.

Pada studi literatur, peneliti mengadaptasi enam langkah penelitian kepustakaan yaitu (1) Pengumpulan referensi (literatur), di mana sumber data diperoleh melalui beberapa teknik, yaitu mengumpulkan dan mereviu literatur pada jurnal Nasional maupun jurnal Internasional mengenai pemanfaatan media komunikasi sosial sebagai sarana pendidikan, menelusuri praktek-praktek pendidikan dan/atau dakwah Islam dengan sarana media sosial, melakukan penelusuran digital tentang media sosial dengan menggunakan kata kunci, data pengguna internet dan media sosial di dunia dan di Indonesia, data pengguna internet berdasarkan umur, langkah-langkah membuat konten menarik di media sosial, dan media sosial keagamaan Islam yang memiliki jumlah follower dan subscriber terbanyak di Indonesia, (2) Memanfaatkan Instrumen penelitian yang berupa daftar check-list pengklasifikasian literatur penelitian berdasarkan fokus kajian, skema penulisan, dan format laporan penelitian, (3) Menganalisis data yang terkumpul dengan analisis isi (content analysis), (4) Perumusan awal hasil kajian, (5) Pengecekan antar literatur dan reviu ulang pustaka untuk menghindari terjadinya misinformasi dan kesalahan dalam memahami teks literatur., (6) Merumuskan simpulan penelitian secara sistematis dan mudah dipahami.

\section{HASIL DAN PEMBAHASAN}

Klaus Schwab (2017) merupakan tokoh yang pertama kali memperkenalkannya era industri 4.0 di dalam karyanya yang berjudul "The Fourth Industrial Revolution". Schwab menjelaskan bahwa saat ini, perkembangan dunia berada pada awal perubahan besar yang mengubah cara hidup secara mendasar. Perubahan yang terjadi sangat dramatis dan mempengaruhi berbagai lini kehidupan umat manusia. Inilah yang disebut sebagai revolusi 
digital dan era disrupsi teknologi atau juga populer disebut dengan era industri 4.0. Revolusi digital adalah penamaan atas terjadinya proliferasi komputer dan otomatisasi pencatatan di semua bidang. Sedangkan sebutan era disrupsi teknologi diberikan karena berkembangnya otomatisasi dan keterhubungan di semua bidang yang menyebabkan perkembangan dunia industri dan kompetisi dunia kerja menjadi tidak linear (Ghufron, 2018).

Karakteristik yang dimiliki oleh era industri 4.0 adalah penerapan kecerdasan buatan. Kecanggihan teknologi mendorong terjadinya migrasi otomatisasi sistem hampir di semua bidang. Teknologi menghadirkan metode baru yang menggabungkan dunia fisik, digital, dan unsur-unsur kehidupan secara fundamental telah mengubah pola kehidupan dan interaksi masyarakat, tak terkecuali termasuk bidang pendidikan (Tjandrawinata, 2016). Kondisi inilah yang kemudian mendorong dilakukannya berbagai inovasi di dalam bidang pendidikan. Pemanfaatan medsos sebagai sarana pembelajaran merupakan salah satu bentuk response Pendidikan terhadap era revolusi digital ini. Pengguna media ini semakin meningkat dari waktu ke waktu, sebagaimana laporan dari Hootsuite (Global Webindex dari Andilink, 2019) sebagaimana grafik sebagai berikut.

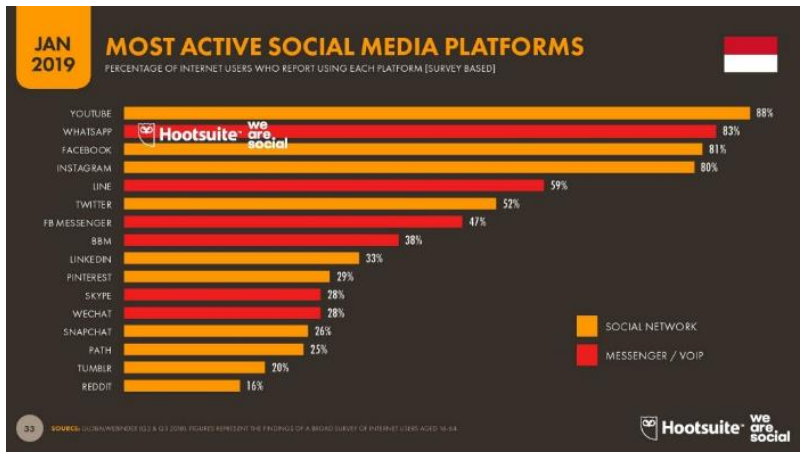

Gambar 1. Laporan Hootsuite Tahun 2019 tentang Pengguna Medsos di Indonesia

Grafik tersebut di atas memberikan ilustrasi prosentase jumlah pengguna sosial media yang aktif di Indonesia yang menunjukkan jumlah pengguna yang besar. Hal ini menjadikan isu penggunaan sosial media sebagai mesia pembelajaran menjadi kebutuhan yang menarik, sehingga untuk memaksimalkan upaya ini, perlu dibarengi dengan strategistrategi yang mendukung ikhtiar tersebut. Ada beberapa strategi yang perlu dilakukan, antara lain sebagai berikut.

\section{Pemilihan Prioritas Platform Media Sosial}

Hasil survei yang dilakukan oleh APJII (2018) tentang pengguna internet berdasarkan umur dapat digambarkan melalui grafik sebagai berikut (Untari, 2019).

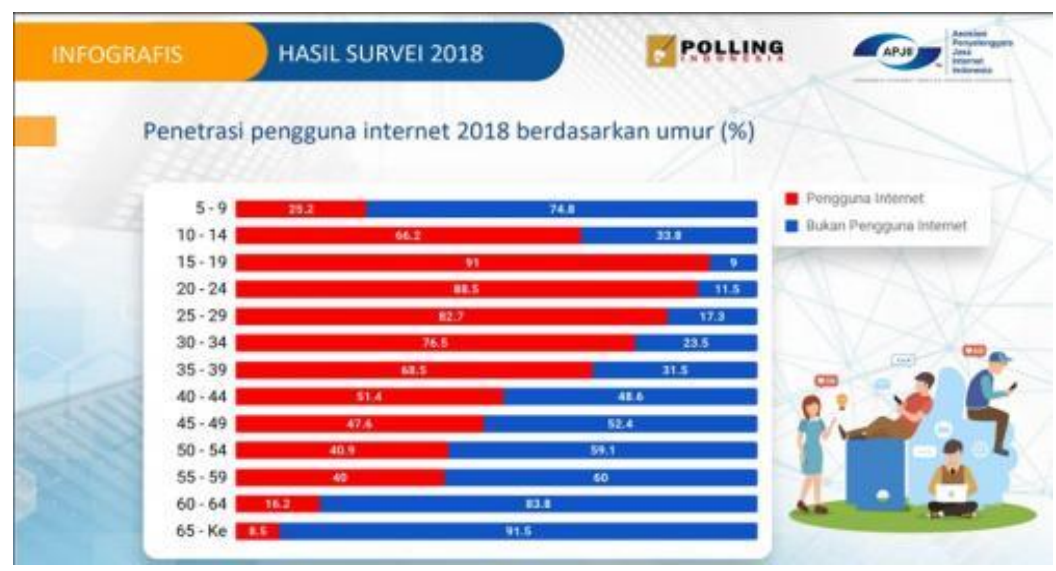

Gambar 2. Data Survei Pengguna Internet Berdasarkan Umur

Berdasarkan gambar 1 di atas, diketahui bahwa pengguna internet paling banyak adalah remaja dari rentang umur 15-19 tahun sebanyak 91\%, 20-24 tahun sebanyak 88,5\%. Sedangkan 
berdasarkan data hasil survei yang dilakukan oleh Hootsuite (2019) yang dipaparkan di atas, banyak diminati dapat di uraikan sebagai berikut.

5 besar platform media sosial yang paling

Tabel 1. Data Lima Besar Pengguna Media Sosial di Indonesia

\begin{tabular}{ccc}
\hline No & Nama Medsos & Jumlah Pengguna \\
\hline 1 & Youtube & $88 \%$ \\
2 & Facebook & $81 \%$ \\
3 & Instagram & $80 \%$ \\
4 & Twiter & $52 \%$ \\
5 & Linkedin & $33 \%$ \\
\hline
\end{tabular}

Seumber: Hootsuite (2019), diolah

Berdasarkan tabel 1 di atas, maka pemilihan platform media sosial sebagai sarana pembelajaran bagi remaja dapat memprioritaskan pada lima media, yaitu: Youtube, Facebook, Instagram, Twiter, dan Linkedin. Di antara kelima media sosial ini, Youtube memiliki posisi terpopuler dibandingkan dengan empat media lainnya. Popularitas tertinggi dipicu oleh nilai manfaat yang diperoleh dari fitur yang ditawarkan oleh media tersebut. Para pengguna media ini memanfaatkan layanan Youtube untuk memenuhi berbagai kebutuhan seperti: mendapatkan hiburan, berbagi informasi, bisnis, dan juga sebagai sarana untuk belajar. Hasil survei Google melaporkan bahwa 57 $\%$ pengguna Youtube berselancar di dunia maya untuk mencari hiburan, dan sebanyak 86 $\%$ mengungkapkan bahwa tujuan mereka mengunjungi situs tersebut adalah untuk memperoleh informasi terkini (Praditya, 2018).

Pengguna internet di Indonesia yang mengakses media sosial tidak saja berasal dari masyarakat yang tinggal di daerah perkotaan (urban), tetapi juga masyarakat yang tinggal di wilayah pinggiran (rural) (Yaya, Khalida, Anggun, Observasi dan Interviu, Juni 2020). Hal ini disebabkan oleh beberapa hal, antara lain: infrastruktur jaringan internet yang semakin baik dan menjangkau daerah-daerah pinggiran, harga paket data yang semakin terjangkau, dan konten yang sesuai dengan kebutuhan masyarakat luas. Kategori konten media sosial yang diminati oleh masyarakat urban dan rural memiliki karakteristik yang berbeda. Masyarakat urban lebih memerlukan konten yang bersifat menunjang kehidupan sehari-hari, di antaranya tema travel, lifestyle atau video tutorial. Sementara masyarakat rural secara umum lebih tertarik ke konten yang berisi hiburan secara langsung seperti musik, komedi, atau sepak bola (Praditya, 2018). Menyikapi hal ini, konten yang dipersiapkan untuk memanfaatkan media sosial sebagai sarana pendidikan perlu disesuaikan dengan karakteristik kebutuhan masyarakat yang menjadi sasaran. Jikalau konten tersebut ditujukan untuk masyarakat rural, maka dibutuhkan kreasi yang dapat mengkombinasikan antara tema-tema traveling dan lifestyle dengan nilai-nilai pendidikan Islam. Demikian juga jika sasaran yang ditetapkan adalah masyarakat rural, maka konten yang dikembangkan sebaiknya memiliki dimensi hiburan, misalnya dalam bentuk komedi Islami, musik Islami, dan lain semacamnya.

\section{Memperhatikan Kebutuhan Remaja}

Penelitian Prabowo \& Hasbiansyah (2019) menemukan bahwa terdapat hubungan yang signifikan antara akses media sosial dengan kebutuhan netizen. Para netizen yang sebagian besar di antaranya berasal dari generasi millennial digerakkan oleh kebutuhan mereka dalam mengakses media sosial. Beberapa orang remaja yang diwawancarai mengungkapkan bahwa mereka hampir setiap saat mengakses youtube, facebook, dan Instagram untuk berbagai keperluan, seperti: sarana komunikasi dengan teman, wahana memperoleh informasi, hiburan, dan sekedar mengisi waktu untuk mengusir kejenuhan (Indah, Feri, Agus, Interviu, Juni 2020).

Pemetaan kebutuhan ini pernah dilakukan melalui penelitian Setiasih \& Puspitasari (2015). Puspitasari (2014). Penelitian tersebut mengungkapkan tentang kebutuhan yang 
mendorong remaja menggunakan media sosial untuk mengirim foto atau video berdasarkan teori kebutuhan Murray (1938) (Schultz, 2008). Hasil dari penelitian itu menunjukkan bahwa terdapat empat kebutuhan remaja yang sangat dominan, yaitu: (1) kebutuhan bermain untuk bersenang-senang dengan sesama mereka tanpa memiliki tujuan tertentu (play) sebesar $83.3 \%$, (2) kebutuhan untuk membangun suatu citra, kesan, agar disaksikan dan didengar, membangun pribadi yang menarik, dan bermaksud menghibur (exhibition) sebesar $70 \%$, (3) kebutuhan terhubung atau bersosialisasi dengan orang lain (affiliation) sebesar 66\%, dan (4) kebutuhan akan pengetahuan dan informasi (understanding) sebesar $63.3 \%$.

Strategi penggunaan media sosial sebagai media penanaman nilai-nilai pendidikan Islam setidaknya dirancang dengan memperhatikan empat kebutuhan tersebut di atas. Kebutuhan akan keilmuan telah memiliki ruang dan menempati posisi terbesar ke empat dalam peta kebutuan remaja tekait dengan penggunaan media sosial. Ini merupakan hal positif yang perlu didukung dengan pemenuhan kebutuhan lainnya. Pemenuhan kebutuhan informasi dan keilmuan harus dapat dikemas dengan menyenangkan (play), memikat (exhibition), dan bahkan diarahkan agar menjadi sarana untuk membangun sosialisasi dengan lingkungannya (affiliation).

\section{Mengedepankan Problem Solving Generasi Millenial}

Setiap generasi memiliki persoalannya masing-masing, begitupun dengan remaja, mereka memiliki permasalahan-permasalahan yang memerlukan solusi. Hal ini sebagai respons atas perkembangan zaman yang berdampak kepada kompleksitas permasalahan yang dihadapi oleh remaja. Selama pandemi covid-19, banyak persoalan baru yang membutuhkan penjelasan secara agama Islam, misalnya: penutupan (lockdown) masjid, shalat Jum'at, dan shalat Ied di masa pandemi ini. Inilah beberapa contoh yang diharapkan dapat ditemukan jawabannya secara mudah di media sosial (Yaya, Anggun, Feri, Interviu, Juni 2020).
Materi yang pilih untuk kepentingan pendidikan Islam di media sosial sebaiknya merupakan jawaban aktual dari permasalahanpermasalahan yang dialami oleh mereka dalam konteks kekinian. Inilah yang dimaksud oleh Syekh al-Baby al-Khuli yang menerangkan bahwa suatu ajakan (pendidikan) harus dapat memberikan solusi atas berbagai problem kehidupan remaja, memindahkan mereka dari suatu situasi ke situasi yang lebih baik (alKhuli, 1952: 27). Pemindahan situasi ini mengandung pengertian yang luas, mencakup seluruh aspek kehidupan remaja. Misalnya, pemindahan dari situasi keburukan menjadi situasi kebaikan, dari situasi keterbelakangan menjadi situasi kemajuan, dari situasi kegalauan kepada situasi ketenangan dan kedamaian, dan lain sejenisnya. Pendekatan problem solving ini dapat dilakukan dengan menawarkan konten media sosial yang berisi konsultasi ataupun tanya jawab atas berbagai problem sosial keagamaan yang dialami oleh remaja.

\section{Strategi Pemilihan dan Pengemasan Konten}

Konten atau materi yang disampaikan melalui media sosial ini adalah ajaran-ajaran Islam yang bersumber dari Alquran dan alHadis. Pemilihan-pemilihan konten yang dipaparkan hendaknya memotivasi remaja untuk lebih mencintai Islam, sehingga akan menggugah mereka berperilaku berdasarkan wawasan Qurani dengan mempertimbangkan kebutuhan dan problematika yang mereka hadapi. Beberapa orang remaja menyatakan bahwa kriteria konten media sosial yang menarik antara lain; tampilan enak dilihat, tema kekinian (aktual), dan bahasa yang digunakan jelas tidak berbelit-belit, dan lagi waktu lebih leluasa digunakan musim covid19 ini (Feri, Agus, Anggun, Yaya, Interview, Juni, 2020).

Langkah untuk membuat konten di media sosial dapat dikembangkan berdasarkan best practise yang telah dilakukan oleh para praktsi muda di media sosial. Elitmarketer (2020) menuliskan beberapa trik untuk membuat konten medsos yang menarik dan atraktif, yaitu: membuat konten yang dapat menjangkau semua kalangan, memastikan bahwa konten membahas topik secara lengkap, menampilkan konsep baru, atau membahas sesuatu dengan perspektif yang berbeda, fokus pada jaringan 
yang ditargetkan, membuat daftar konten yang menarik, membuat konten yang ramah dan bermaksud berbagi di media sosial, serta membuat format postingan yang enak dilihat. Sementara itu, trik yang dibagikan oleh Kimberly Stephanie (2020) meliputi: menetapkan tujuan, membuat konten yang berkualitas dan sesuai tren yang berkembang, konten harus sesuai dengan kebutuhan audiens anda, mendaur ulang konten lama dengan konteks tren yang baru (repurpose), serta mempromosikan dan mendistribusikan konten melalui saluran-saluran media digital.

Langkah-langkah tersebut di atas merupakan upaya minimal dan dapat dikembangkan lagi dengan cara membandingkannya dengan konten-konten yang telah teruji diminati oleh masyarakat. Salah satu indikatornya adalah akun medsos tersebut memiliki jumlah follower dan subscriber yang banyak. Hasil penelusuran dan observasi di media digital menunjukkan adanya beberapa akun yang terkait dengan pendidikan atau dakwah Islam yang memiliki jumlah follower dan subscriber terbanyak di Indonesia pada platform media sosial youtube, yaitu: akun @aagym milik K.H. Abdullah Gymnastiar dengan 5 juta follower dan 221 ribu subscriber, @adihidayatofficial milik ustad Adi Hidayat dengan 2,4 juta follower dan 369 ribu subscriber, @hanan_attaki milik Ustad Hanan Attaki dengan 7,8 juta follower dan 823 ribu subscriber,dan@ustadzabdushomad_official dengan 1 juta subscriber (Sukandar, 2019). Kendati demikian, keempat akun tersebut perlu ditelaah dari segi konten, pendekatan, dan platform syiar Islam yang ramah untuk memperoleh sebuah format media sosial di bidang pendidikan Islam yang lebih baik.

\section{Pendekatan Persuasif-Humanis}

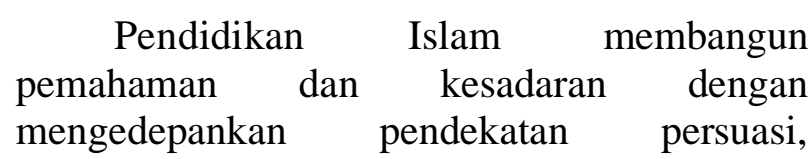
memengaruhi manusia agar melaksanakan ajaran agama sesuai dengan kesadaran dan atas kemauannya sendiri, bukan dengan cara paksaan. Pendekatan ini mengedepankan prinsip-prinsip perikemanusiaan dan hak asasi manusia dalam beragama (Basuki, 2006). Para remaja mengungkapkan bahwa postingan pesan moral di Youtube, Facebook, dan Instagram yang berkesan adalah pesanpesan yang disampaikan dengan bahasa yang lembut, tidak bernada menyinggung, dan katakata yang dapat menyentuh hati mereka (Agus, Yaya, Feri, Interviu, Juni 2020). Dalam pada itu, maka strategi pemanfaatan medsos untuk penanaman nilai-nilai Pendidikan Islam seharusnya menempuh pendekatan persuasifhumanis, materi yang rasional, dan disampaikan dengan cara rasional (rational necessary and rational intellection) (al-Faruqi, 1976) dalam rangka memfasilitasi manusia agar berperilaku sesuai dengan fitrahnya.

$\begin{array}{ccc}\text { Pendidikan } & \text { humanistik } & \text { bermakna } \\ \text { menekankan } & \text { pentingnya } & \text { nilai-nilai }\end{array}$
kemanusiaan, membantu manusia menjadi lebih manusiawi, lebih berbudaya, sebagai sosok manusia seutuhnya. Konsepsi ajaran humanistik menjelaskan bahwa audien pendidikan merupakan subyek yang aktif dalam berinteraksi dengan lingkungannya. Pendidikan humanis mengadopsi prinsip-prinsip pendidikan dari dua aliran, yaitu: progresivisme dan eksistensialisme. Prinsip progresivisme memandang pendidikan berpusat pada anak (subyek pendidikan), menempatkan guru sebagai sosok yang demokratis, berfokus pada keterlibatan dan keaktifan siswa secara kooperatif. Sedangkan prinsip eksistensialisme menekankan pada keunikan yang dimiliki oleh siswa sebagai individu, mereka dipandang sebagai pribadi-pribadi yang memiliki keunikan, sehingga berbeda antara siswa satu dengan siswa lainnya (Knight, 1982: 21; Barnadib, 1996: 29). Hal ini menjadi pertimbangan dalam memahami audien di media sosial yang sudah barang tentu berasal dari berbagai latar belakang dan karakter individu yang unik. Oleh karena itu, maka konten bermuatan pendidikan hendaknya dirancang dengan memperhatikan nilai-nilai universal.

\section{Menampilkan Platform Syiar Islam yang Ramah}

Media sosial memiliki posisi strategis sebagai sarana untuk membangun opini, pemahaman, dan citra berbagai produk dan ideologi. Keterbukaan media sosial mendorong pihak-pihak tertentu memanfaatkannya sesuai dengan kepentingan kelompoknya. Narasinarasi keagaamaan Islam berhaluan keras 
seringkali mewarnai media sosial (Heri, Yaya, Anggun, Interviu, Juni 2020). Hal ini perlu direspons secara bijaksana agar dapat memanfaatkan media sosial sebagai sarana untuk membangun syiar visi agama Islam sebagai penebar rahmad bagi sekalian alam (rahmatan lil 'alamin) (Purwanto, Qowaid, \& Fauzi, R. (2019). Syiar merupakan bentuk dari propaganda kebenaran (truthful propagation) yang memiliki batas-batas etika dan prinsipprinsip yang didasarkan pada Alquran dan Sunnah (Taufik, 2008: 89). Adapun prinsipprinsip tersebut meliputi: tawasuth, tasammuh, tawazun, ta'adul, dan amar ma'ruf nahi mungkar:

Prinsip tawasuth telah dijelaskan di dalam Alquran surat al-Baqarah ayat 134. Tawasuth dapat dimaknai sebagai jalan tengah di antara sikap keras (radikal) dan terlalu bebas (liberal) (Mannan, 2012:36). Sikap tengah ini juga merujuk pada suatu kearifan untuk menerima ketetapan Allah (sunatullah) sebagai anugerah dalam kehidupan manusia dan menempatkan diri dalam kehidupan bermasyarakat secara tidak berlebihan. Atas dasar itu, maka monopoli kebenaran tunggal yang menafikan perbedaan dan sikap liberal dalam beragama telah menciderai kearifan tersebut. Prinsip tawasuth berisi sikap hidup yang berupaya menjunjung tinggi keharusan adil di tengah-tengah kehidupan bersama dan menghindari segala bentuk pendekatan yang bersifat tathorruf atau ekstrimisme-keras dan ekstrimisme-bebas (Shaleh, 2020).

Prinsip Tasamuh berasal dari bahasa Arab yang sepadan dengan kata "lapang dada", dan "suka memaafkan". Sikap lapang dada merupakan kepribadian mulia yang diperlukan untuk mengelola perbedaan dalam kehidupan masyarakat yang majemuk. Perbedaan merupakan anugerah yang perlu disikapi secara arif dan bijaksana untuk dapat menumbuhkan energi positif dalam upaya membangun masa depan bangsa. Anugerah ini akan berubah menjadi malapetaka, jika ditempatkan sebagai garis "pemisah" dan "pembatas" yang dapat memicu polemik, perpecahan, dan perseteruhan. Sikap tasammuh (toleransi) dapat menghapuskan garis pemisah dan pembatas tersebut, kemudian membentuk persatuan dan kerjasama. Sikap ini dapat digali di dalam alQur'an Surat Thaha ayat 44 (Shaleh, 2020).

Prinsip tawazun ini telah digambarkan di dalam surat al-Hadid ayat 25. Prinsip ini berisi sikap untuk menyelaraskan berbagai hal dalam kehidupan terkait hubungan dengan sang pencipta (hablum min Allah) dan hubungan dengan sesama manusia (hablum min an-nas). Dalam hal pengambilan hukum, keseimbangan ini juga termasuk penggunaan akal (Aqli) dalam memahami dalil dari Syara' (Naqli). Penggunaan akal diperlukan untuk menemukan pemahaman terhadap nash (teks) yang bersifat dhanni (speculative), namun tidak boleh berdiri sendiri dan terlepas dari dalil-dalil syara' yang qoth'i (definitive) (Shaleh, 2020)

Prinsip Ta'âddul menjadi semangat untuk selalu menegakkan keadilan dan kejujuran kepada siapapun, dimanapun, dan dalam kondisi apapun dengan pertimbangan kemaslahatan umat sekalian alam (Manan, 2012). Prinsip ini sesuai dengan ajaran Islam yang termaktub di dalam al-Qur'an Surat al Maidah ayat 8. Prinsip ta'adul menyangkut pertimbangan secara sosiologis, psikologis, dan kemaslahatan lainnya (Qomar, 2014).

Kaidah-kaidah prinsip tersebut di atas menjadi fondasi untuk membangun syiar adalah ajaran tentang tanggungjawab sosial melalui amar ma'rûf nahi munkar yang diperintahkan di dalam al-Qur'an surat Ali Imron ayat 110 agar ummat Islam dapat menjadi "ummat terbaik". Syiar ini diharapkan dapat membangun kepekaan dan kesadaran untuk selalu melakukan perbuatan yang baik dan bermanfaat bagi ummat (ma'ruf), dan menjaga diri untuk mencegah segala hal yang dapat merendahkan nilai-nilai kemanusiaan (Siddiq, 2005). Upaya amar al-ma'ruf nahi al-munkar yang menjadi gerakan arus utama yang mengarah kepada terbangunnya kehidupan masyarakat yang cinta damai, saling menghormati, dan menghargai perlu ditanamkan kepada generasi muda dengan pendekatan pendidikan. Hal ini sangat dibutuhkan untuk membuktikan bahwa Islam bukan ancaman bagi ummat selainnya, juga bukan sebagai wadah dari kejahatan mutlak yang seringkali dituduhkan oleh ummat lain (Bravo López, 2014). 
Implementasi amar al-ma'ruf nahi almunkar akan memenuhi prinsip takwa sebagai suatu konsep ideal Muslim untuk mencapai keshalihan (piety) (Taufik, 2008: 108). Bangunan takwa merupakan suatu sikap religius yang mendorong lahirnya sikap dan tindakan yang ma'ruf dan menjauhi yang mungkar dalam kehidupan sehari-hari guna menjalankan perintah-perintah Allah dan menjauhi larangan-Nya. Hal ini menjadi strategi Pendidikan Islam yang perlu disyiarkan melalui sarana media sosial.

\section{PENUTUP}

Jumlah pengguna media sosial yang sangat besar perlu disikapi oleh pelaku-pelaku Pendidikan Islam informal dengan melakukan inovasi-inovasi pemanfaatan media tersebut untuk meningkatkan kinerja pendidikan informal itu sendiri. Terlebih lagi di masa pandemi covid-19 sekarang ini, sarana media digital dapat menjadi solusi atas dibatasinya perjumpaan fisik antar manusia. Namun demikian, untuk dapat memaksimalkan pemanfaatan media sosial sebagai sarana Pendidikan Islam informal bagi remaja, perlu dikembangkan lagi dengan memperhatikan langkah-langkah strategis sebagaimana dijabarkan di atas. Hal ini dapat membantu agar target Pendidikan informal lebih tepat sasaran untuk membangun wajah Islam yang ramah dan cinta damai di kalangan generasi penerus bangsa.

Strategi yang dirumuskan di dalam penelitian ini adalah langkah minimal yang perlu pengembangan lebih lanjut agar dapat membangun model-model pendidikan berbasis teknologi digital yang lebih tepat guna, tepat waktu, dan tepat sasaran. Kendati demikian langkah-langkah ini dapat dipertimbangkan untuk berupaya mewarnai ruang media komunikasi sosial dengan konten-konten keIslaman yang sejuk, ramah, dan penuh hikmah. Hal ini perlu diikuti dengan kesadaran bahwa perkembangan teknologi digital ini berjalan sangat cepat, era industrial 4.0 akan segera disusul dengan era industri 5.0 dan akan terus mengalami perkembangan di kemudian hari. Hal ini perlu direspons secara cepat dengan memanfaatkannya sebagai mesin-mesin pendidikan untuk terwujudnya masyarakat
Indonesia yang sejahtera, adil, makmur di dunia dan di akherat kelak.

\section{DAFTAR PUSTAKA}

Abidin, J., \& Fahmi, I. (2019). Media Sosial dalam Mempengaruhi perilaku Keberagamaan Siswa dan solusinya melalui Pendidikan Agama Islam. Wahana Karya Ilmiah, 3(01).

Agus, M. (2020). Diinterviu oleh Shaleh, 5 Juni.

Ainiyah, N. (2018). Remaja Millenial dan Media Sosial: Media Sosial Sebagai Media Informasi Pendidikan Bagi Remaja Millenial. Jurnal Pendidikan Islam Indonesia, 2(2), 221-236.

Akbar, R. R. A. (2018). Pengembangan Video Pembelajaran Matematika Berbantuan Media Sosial Instagram sebagai Alternatif Pembelajaran (Doctoral dissertation, UIN Raden Intan Lampung).

al-Baby Al-Khuli. (1952). Tazkirah Al-Da'wah. Mesir: al-Kitab, al-Arabi.

al-Faruqi, I. I. (1976). On the nature of Islamic da'wah. International Review of Mission, 65(260), 391-409.

Andilink. (2019). Hootsuite (We are Social): Indonesian Digital Report 2019. Tersedia pada: https://andi.link/hootsuite-we-aresocial-indonesian-digital-report-2019/ (Diakses: 1 Juli 2020).

Anggun, F. (2020). Diinterviu oleh Shaleh, 11 Juni.

APJII. (2019). Survei APJII yang Ditunggutunggu, Penetrasi Internet Indonesia $2018 . \quad$ Tersedia pada: https://apjii.or.id/downfile/file/BULETI NAPJIIEDISI40Mei2019.pdf.

Arkoun, M. (1994). Nalar Islami dan nalar modern: berbagai tantangan dan jalan baru. INIS.

Barnadib, I. (1996). Dasar-dasar kependidikan: memahami makna dan perspektif beberapa teori pendidikan. Jakarta: Ghalia Indonesia, 41-45.

Bravo López, F. (2014). The Genocidal Islamophobia of a Late NineteenthCentury French Anti-Semite: D. Kimon 
and The Pathology of Islam. Islam and Christian-Muslim Relations, 25 (1), 101116.

https://doi.org/10.1080/09596410.2013.8 24171.

Basuki, B. (2006). Mengonstruksi Pendidikan Kritis Humanis dan Populis; Tinjauan Tentang Politik Pendidikan Indonesia Era Globalisasi Informasi. Edukasi, 4(2), 294727.

Buana, D. R. (2020). Analisis Perilaku Masyarakat Indonesia dalam Menghadapi Pandemi Virus Corona (Covid-19) dan Kiat Menjaga Kesejahteraan Jiwa. Salam: Jurnal Sosial dan Budaya Syar-i,7(3), 217-226.

Chandra, R. I. (1996). Teologi dan Komunikasi. Yogyakarta: Duta Wacana University Press.

Elitmarketer. (2020). 7 Tips untuk Membuat Konten Viral di Media Sosial. Tersedia pada: https://elitemarketer.id/content/7tips-untuk-membuat-konten-viral-dimedia-sosial/. (Diakses 1 Juli 2020).

Feri, A. (2020). Diinterviu oleh Shaleh, 7 Juni.

Ghufron, G. (2018, September). Revolusi Industri 4.0: Tantangan, Peluang, Dan Solusi Bagi Dunia Pendidikan. In Seminar Nasional dan Diskusi Panel Multidisiplin Hasil Penelitian dan Pengabdian Kepada Masyarakat 2018 (Vol. 1, No. 1).

Griffin, E.M. 2003. A First Look at Communication Theory 5th Edition. McGraw Hill, New York.

Hebdige, D. (1995). Subculture: The meaning of style. Critical Quarterly, 37(2), 120124.

Huberman, A. M., Miles, M., \& Saldana, J. (2014). Qualitative data analysis: A methods sourcebook. The united states of America: SAGE publications.

Indah, F. (2020). Diinterviu oleh Shaleh, 1 Juni.

Khalida, Z. (2020). Diinterviu oleh Shaleh, 10 Juni.
Knight, G. R. (2008). Issues and alternatives in educational philosophy. Andrews University Press.

Mannan, Abdul. (2012). Ahlussunnah wal Jamaah Akidah Umat Islam Indonesia. (Kediri: PP. Al Falah Ploso Kediri.

Morissan, dkk. 2010. Teori Komunikasi Massa. Bogor, Ghalia Indonesia.

Murray, H. A. (1938). Explorations in personality: A clinical and experimental study of fifty men of college age.

Prabowo, D. R., \& Hasbiansyah, O. (2019). Hubungan Tayangan Youtube Yufid. TV dengan Pemenuhan Kebutuhan Informasi Netizen Tentang Islam.

Praditya, D. (2018). 3 Fakta Menarik dari Riset Google tentang Perkembangan YouTube di Indonesia. Tersedia pada: https://id.techinasia.com/faktaperkembangan-youtube-di-indonesia. Diakses: 3 Juli 2020.

Purwanto, Y., Qowaid, Q., \& Fauzi, R. (2019). Internalisasi Nilai Moderasi Melalui Pendidikan Agama Islam di Perguruan Tinggi Umum. Edukasi, 17(2), 294708

Qomar, M. (2002). NU "Liberal": Dari Tradisionalisme Ahlussunnah ke Universalisme Islam, introd. Azyumardi Azra, Bandung: Mizan.

Schultz, D. S. S. (2008). Theories of Personality (Chapter 5). Ditemu kembali dari: http://cengagesites.com/academic/assets/ sites/Schultz_Ch05.pdf

Schwab, K. (2017). The fourth industrial revolution. Currency.

Setiasih, S., \& Puspitasari, F. I. (2015). Kebutuhan remaja untuk mengirim foto atau video di Instagram. Jurnal Psikologi Ulayat: Indonesian Journal of Indigenous Psychology, 2(2), 461-472.

Shaleh, S., Zamroni, Z., Mukminan, M., Zakaria, Bin A., Ramadhan, S. (2020). Formulating strategies against student radicalism: a case of madrasah in Indonesia. International Journal of Psychosocial Rehabilitation, 24 (10). DOI: 10.37200/IJPR/V24I10/PR300174. 
Siddiq, Achmad. (2005). Khitah Nahdliyah, Surabaya: Khalista-LTNU, Cet.III.

Sindang, E. (2013). Manfaat Media Sosial dalam Ranah Pendidikan dan Pelatihan. Jakarta: Pusdiklat KNPK.

Stephanie K. (2020). Agar Strategi Marketing Anda Terpenuhi, Coba 5 Tips Membuat Konten Marketing yang Menarik Ini. Tersedia pada: https://koinworks.com/blog/membuatkonten-marketing/. (Diakses pada 1 Juli 2020).

Sukandar. C. A. (2019). Dakwah Lewat YouTube, 4 Ustad Kondang. Tersedia pada:

https://www.wartaekonomi.co.id/read257 504/dakwah-lewat-youtube-4-ustadkondang-ini-dapat-penghasilansebesar/2. (Diakses pada 2 Juli 2020).

Taufik M. T. (2008). Etika Komunikasi Islam Kritik terhadap Konsep Komunikasi Barat. Bandung: Sahifa.

Taufiq, F., \& Utama, L. W. P. (2018). Media Sosial dan Gerakan Sosio-Politik Umat Islam di Indonesia. FIKRAH, 6(2), 391408.

Tjandrawinata, R.R. (2016). Industri 4.0: Revolusi industry abad ini dan pengaruhnya pada bidang kesehatan dan bioteknologi. Jurnal Medicinus, Vol 29, Nomor 1, Edisi April.

Triastuti, R. (2019). Peran Media Sosial Sebagai Alat Diplomasi Digital Global Dalam Upaya Meningkatkan Nation Branding Indonesia Di Era Pemerintahan Joko Widodo. (Disertasi, Universitas Pembangunan Nasional Veteran Jakarta).

Tribunnews. (2019). Pengguna Sosial Media di Indonesia Terbesar Keempat di Dunia. Tersedia pada: https://www.tribunnews.com/techno/201 9/06/19/pengguna-sosial-media-diindonesia-terbesar-keempat-di-dunia (Diakses: 1 Juli 2020).

Untari, P. H. (2019). 2018, Pengguna Internet Indonesia Paling Banyak di Usia 15-19 Tahun. Tersedia pada: https://techno.okezone.com/read/2019/05 /21/207/2058544/2018-penggunainternet-indonesia-paling-banyak-diusia-15-19-tahun. (Diakses: 1 Juli 2020)

Wahid, A. H., Muali, C., \& Putri, A. A. (2018). Rekonstruksi Pendidikan Islam Kontemporer Dalam Perspektif Transformasi Sosial. HIKMAH: Jurnal Pendidikan Islam, 7(1), 1-21.

Yaya, S. (2020). Diinterviu oleh Shaleh, 10 Juni. 